IZA DP No. 6075

Unemployment Benefits and Immigration:

Evidence from the EU

Corrado Giulietti

Martin Guzi

Martin Kahanec

Klaus F. Zimmermann

October 2011 


\title{
Unemployment Benefits and Immigration: Evidence from the EU
}

\author{
Corrado Giulietti
}

IZA

\author{
Martin Guzi
}

IZA

Martin Kahanec

Central European University and IZA

Klaus F. Zimmermann

IZA and University of Bonn

\section{IZA Discussion Paper No. 6075 \\ October 2011}

\author{
IZA \\ P.O. Box 7240 \\ 53072 Bonn \\ Germany \\ Phone: +49-228-3894-0 \\ Fax: +49-228-3894-180 \\ E-mail: iza@iza.org
}

Any opinions expressed here are those of the author(s) and not those of IZA. Research published in this series may include views on policy, but the institute itself takes no institutional policy positions.

The Institute for the Study of Labor (IZA) in Bonn is a local and virtual international research center and a place of communication between science, politics and business. IZA is an independent nonprofit organization supported by Deutsche Post Foundation. The center is associated with the University of Bonn and offers a stimulating research environment through its international network, workshops and conferences, data service, project support, research visits and doctoral program. IZA engages in (i) original and internationally competitive research in all fields of labor economics, (ii) development of policy concepts, and (iii) dissemination of research results and concepts to the interested public.

IZA Discussion Papers often represent preliminary work and are circulated to encourage discussion. Citation of such a paper should account for its provisional character. A revised version may be available directly from the author. 
IZA Discussion Paper No. 6075

October 2011

\begin{abstract}
Unemployment Benefits and Immigration: Evidence from the EU

The paper studies the impact of unemployment benefits on immigration. A sample of 19 European countries observed over the period 1993-2008 is used to test the hypothesis that unemployment benefit spending (UBS) is correlated with immigration flows from EU and nonEU origins. While OLS estimates reveal the existence of a moderate correlation for non-EU immigrants only, IV and GMM techniques used to address endogeneity issues yield, respectively, a much smaller and an essentially zero causal impact of UBS on immigration. All estimates for immigrants from EU origins indicate that flows within the EU are not related to unemployment benefit generosity. This suggests that the so-called "welfare migration" debate is misguided and not based on empirical evidence.
\end{abstract}

JEL Classification: H53, J61

Keywords: immigration, unemployment benefit spending, welfare magnets, European Union

Corresponding author:

Corrado Giulietti

IZA

P.O. Box 7240

53072 Bonn

Germany

E-mail: giulietti@iza.org 


\section{Introduction}

In recent years the topic of "welfare migration" has raised controversial discussions and generated a substantial body of literature. There is concern that excessive participation in welfare or social security systems might be a more common phenomenon for immigrants than for natives (Cohen et al., 2009; Nannestad, 2007) or constitute a fiscal burden for host countries (De Giorgi and Pellizzari, 2009).

The scope of this paper is to explore whether and how changes in countries' welfare generosity affect immigration. Instead of using an aggregate measure of welfare, such as total social public spending (which would include social assistance), this work focuses on unemployment benefits. These benefits result from a public insurance program in which participation is conditioned on compulsory contributions during periods of insured work. The contributory nature of the program makes immigrants' benefit recipiency directly linked to their employment experience. As described by Heitmueller (2005), expected income may be an important factor driving people's decision to migrate. Together with earnings during phases of employment, this also includes unemployment benefits that might be accessed during spells of unemployment. Hence, the presence of unemployment benefits may increase immigrants' expected income as well as help reduce its volatility. As a result, countries with particularly generous unemployment benefits could attract a greater number of (risk averse) immigrants.

This hypothesis is tested by estimating the correlation between immigration inflows and unemployment benefit spending (UBS) as a fraction of the gross domestic product for a sample of European countries. Flows from EU and non-EU origins are analysed separately because immigrants from these two broad origins are likely to respond in different ways to UBS. This could be due to, for example, their diverse socio-economic characteristics or the different treatment in terms of immigration legislation (Anastassova and Paligorova, 2005), or even different eligibility criteria for unemployment program participation. In addition, while immigrants from $\mathrm{EU}$ origins are free to migrate within the EU, migrants from non-EU origins do not have the same freedom.

Building upon recent studies which have found no (Pedersen et al., 2008) or moderate (De Giorgi and Pellizzari, 2009) evidence of the welfare magnet hypothesis, the article's main contribution is that it systematically studies the endogenous nature of UBS in the context of the welfare magnet hypothesis. Specifically, two potential channels of reverse causality between immigration and UBS are explored. The first is a case of simultaneity, whereby immigrants impact UBS through benefit take-up or by affecting the GDP of a country. This hypothesis is investigated by estimating the probability of unemployment benefits recipiency, conditional on unemployment, for both immigrants and natives. By doing so, it is possible to distinguish whether reverse causality arises due to the composition of immigrant population or due to immigrants' higher propensity to be in welfare. The second source of reverse causality relates to how policy reacts to immigration by cutting (or expanding) UBS. This conjecture is investigated by analysing whether changes in eligibility criteria and durations of unemployment benefits are associated with the evolution of immigration patterns.

In order to address the potential endogeneity implied by reverse causality, UBS is instrumented 
with the number of political parties within each winning parliamentary coalition. The rationale is that social expenditure is likely to be higher (lower) in countries where coalitions comprised of more (fewer) political parties (Bawn and Rosenbluth, 2006). While the ordinary least squares (OLS) estimates indicate the existence of a moderate welfare magnet effect for non-EU immigrants, the implementation of instrumental variable (IV) and generalised method of moments (GMM) approaches reveals that the impact becomes smaller and statistically insignificant. This result is taken as evidence that reverse causality produces an upward bias in the correlation between immigration and UBS. Therefore, failing to account for such a mechanism implies an overstating of the effect that an exogenous change in UBS would produce on immigration. The analysis for EU immigrants indicates that they do not react to the UBS in host countries. This result might also reflect the different nature of within-EU migration.

The article is organised as follows. Section 2 reviews studies about the welfare magnet hypothesis. Section 3 provides a description of the data and related summary statistics. The empirical strategy is outlined in Section 4, followed by OLS and IV results. Concluding remarks are to be found in Section 5 .

\section{Literature review}

The focus of the immigration literature on the relationship between welfare and immigration is rather recent. In the context of immigration to the USA, Borjas (1999) proposes that since immigrants in the country have already incurred large costs, they tend to cluster in states offering the highest welfare benefits. Moreover, the generosity of the welfare state will also affect the skill composition of immigration. In their simulations Brücker et al. (2002) find that welfare-generous countries attract relatively more low-skilled workers, whilst high-skilled workers prefer to settle in countries where social spending is lower, due to the lower tax burden needed to finance it. Hence, welfare generosity may induce a negative sorting of immigrants. In the context of EU enlargement Boeri and Brücker (2005) argue that when the risk of being unemployed is greater for immigrants than natives, the incentive to migrate increases with the replacement rate, and mainly for low-skilled individuals.

Several empirical studies have explored the welfare magnet hypothesis. Using the European Community Household Panel for the period 1994-2001, De Giorgi and Pellizzari (2009) estimate the correlation between immigration and the net replacement rate (NRR), used as a proxy for welfare generosity. The NRR is defined as the ratio between unemployment benefits and average wages. They find that welfare generosity acts as a magnet for immigrants, but its impact is relatively weak. On the other hand, labour market conditions in the destination countries (such as unemployment rates and wages) and networks play a vital role on the decision to move. A similar analysis was carried out by Pedersen et al. (2008). Their study, based on detailed immigration flows to OECD countries for the period 1990-2000, mainly focuses on exploring the impact of social networks on immigration. However, their regression analysis also controls for total social expenditure, used as proxy for welfare generosity. Results from their preferred 
specification do not support the existence of a positive correlation between immigration and social expenditure.

To summarise, while theory suggests that immigrants - in particular low-skilled - are more likely to move to generous countries, there is no strong empirical evidence that this is actually the case. This paper contributes to the recent empirical evidence in two ways: first it focuses on unemployment benefits as proxy for welfare generosity. Changes in public insurance programs affect the total income that working immigrants could obtain in the potential country of destination and hence influence their decision to move. Second, issues of endogeneity of welfare generosity are directly addressed by exploring reverse causality between UBS and immigration.

\section{Data}

The sample covers 19 European countries (the EU-15, excluding Greece, for which immigration inflows were not available, plus the Czech Republic, Hungary, the Slovak Republic, Norway and Switzerland) from 1993-2008. ${ }^{1}$ Data were accessed from several sources. Gross immigration inflows come from the OECD Système d'observation permanente des migrations (SOPEMI) database, which provides consistent and harmonised data over time. These are used to calculate immigration inflows expressed as percentage of total population in a country. Missing information on flows from some countries was complemented with the data used in Pedersen et al. (2008). ${ }^{2}$ From SOPEMI, information on the stock of foreign-born population was obtained as well and was used to construct the social network variable (see Pedersen et al., 2008). Data on UBS were collected from the OECD Social Expenditure Database (SOCX), which provides detailed information on social welfare spending in OECD countries. ${ }^{3}$ Complementary information on the characteristics of UBS (such as eligibility criteria and duration) and on expenditure on family, health and pension programmes was collected as well. ${ }^{4}$ Finally, statistics on the unemployment rate and per-capita GDP were obtained from the World Development Indicators (WDI) online database. ${ }^{5}$ Data on the number of parties in government coalitions were collected from the European Election Database. ${ }^{6}$ Summary statistics are reported in Table A1 in the Appendix.

\footnotetext{
${ }^{1}$ EU-15 member states are: Austria, Belgium, Denmark, Finland, France, Germany, Greece, Ireland, Italy, Luxembourg, the Netherlands, Portugal, Spain, Sweden and the United Kingdom. The year 1993 coincides with the abolition of restrictions on internal labour mobility within the then European Community. Starting the analysis from this period facilitates the distinction between EU and non-EU flows. The panel is unbalanced because of the unavailability of data for some years. Details are presented in the Appendix.

${ }^{2}$ We are grateful to Peder Pedersen, Mariola Pytlikova and Nina Smith for kindly providing us part of the data used in their paper.

${ }^{3}$ Source: http://www.sourceoecd.org/database/OECDStat.

${ }^{4}$ Source: OECD (2002), OECD (2007).

${ }^{5}$ Source: http://data.worldbank.org/data-catalog/. Per-capita GDP is PPP adjusted and expressed in 2005 US dollars.

${ }^{6}$ http://www.nsd.uib.no/european_election_database/.
} 


\section{Empirical framework and results}

The hypothesis that immigration flows are correlated with UBS is tested with the following econometric model:

$$
m_{i t}=\alpha+\beta x_{i t-1}+\mathbf{z}_{i t-1}^{\prime} \gamma+\theta_{i}+\theta_{t}+\varepsilon_{i t}
$$

where $m_{i t}$ indicates immigration inflows expressed as percentage of the total population in country $i$ at time $t$, and $x_{i t-1}$ represents UBS. The equation is estimated for both EU and non-EU immigration inflows. The matrix $\mathbf{z}_{i t-1}$ includes, among other covariates, the social network variable. This corresponds to the stock of immigrants from the same origin of the flows (i.e. either EU or non-EU) as a percentage of the total population. Per-capita GDP and the unemployment rate of the destination country are also included in order to control for macroeconomic fundamentals correlated with immigration inflows. To adjust for the fact that immigrants do not immediately respond to incentives in the host countries, all explanatory variables are used in their lagged values. Lags might also address problems of endogeneity, but only partially, especially if persistent unobservable shocks contained in the error term are correlated with both the response variable and the covariates in the left hand side of equation (1). Issues of endogeneity are explored in the next subsection, where IV and GMM approaches are discussed.

The model is estimated using country fixed effects; hence, the parameter of interest $(\beta)$ represents the correlation between immigration inflows and UBS estimated through within-country changes. Year dummies are included as well to control for time-varying shocks common to all countries. In addition, an indicator for the years after the 2004 EU enlargement is introduced to capture changes in immigration patterns common to all receiving countries. ${ }^{7}$ Due to the inhomogeneous size of countries, observations are weighted by population size. ${ }^{8}$

\subsection{OLS results}

Table 1 reports the results of the estimation of OLS regression of equation (1). For sake of comparison, column (a) reports the results of the model without UBS. In such a model one would expect all components of $\mathbf{z}_{i t-1}$ to be correlated with immigration flows. For example, immigrants are more likely to choose locations where individuals from the same origin have already settled. Similarly, a higher per-capita GDP and better employment conditions are expected to attract, all things being equal, more immigrants. The estimates of networks, GDP and unemployment rate seem to confirm this hypothesis; however, the correlation is economically and statistically stronger for non-EU individuals. ${ }^{9}$ For non-EU immigrants GDP is positively

\footnotetext{
${ }^{7}$ While the inclusion of this variable does not substantially change the estimates, it does generally improve the fit of the model.

${ }^{8}$ Since weights must be constant when fixed effects are used, population size in the year 2000 is chosen. Sensitivity tests are carried out to assess the impact of observation weighting.

${ }^{9}$ For example, a change in the stock of EU immigrants of $0.1 \%$ (e.g., from the mean value of 4.5 to $4.6 \%$ ) is associated with an increase of immigration flows which varies between 0.012 and $0.014 \%$ across specifications (at the mean value this corresponds to an increase from 0.44 to around $0.45 \%$ ). On the contrary, the increase of EU immigration flows associated with a $0.1 \%$ change in the network (e.g., from the mean value of 2.0 to $2.1 \%$ ) is around $0.01 \%$ (at the mean value this corresponds to an increase from 0.12 to less than $0.13 \%$ ).
} 
correlated with immigration (the point estimates vary between 0.017 and 0.019 across models), while for immigrants coming from EU countries, this correlation is essentially zero. ${ }^{10}$ While for neither groups of immigrants is it possible to reject the null hypothesis that unemployment is correlated with immigration, the size of the estimate would have been, in any case, negligible. ${ }^{11}$ In column (b), UBS is added to the specification. The estimated coefficient is positive for nonEU immigrants, but negative for EU immigrants, although imprecisely estimated. Taken at its face value, the estimate of 0.058 for non-EU immigrants means that a $1 \%$ change in UBS is associated with a change in immigration flows of less than $0.01 \%$. A practical example is useful: if the UK were to experience a substantial increase in UBS from, say, $1.13 \%$ (the mean value) to $3.15 \%$ (the mean value in Germany), then there would be an associated change in immigration flows from $0.45 \%$ to $0.57 \%$. In this particular case a growth of UBS of a factor of nearly three correlates with a growth of about $1 / 4$ in immigration flows. In contrast, the estimated coefficient for EU immigrants is essentially zero in terms of economic impact.

In column (c), a model which includes other major social expenditure components (health, pensions and family) is estimated. The rationale is to control for potential omitted variables that might confound the correlation between UBS and immigration flows. After including these additional components, the estimate of UBS for non-EU immigrants increases only slightly (0.061 vs 0.058 ) ; however, this difference, besides being statistically insignificant at the $10 \%$ level, is also very small in terms of size. Similarly for EU immigrants, the addition of other expenditure components does not affect the essentially zero estimate. ${ }^{12}$ Finally, in column (d), a model without weights is estimated. The UBS point estimates are, in absolute terms, slightly larger, although the general pattern remains unchanged. The weighted estimates are generally preferred, especially for non-EU immigrants, as they are closer to the predictions of migration theory both in terms of signs and magnitude.

In summary, the OLS analysis demonstrates that there is moderate association between UBS and non-EU immigration inflow; however, the same cannot be said of EU immigrants. It should be noted that these results are mere correlation estimates. Hence a more causal interpretation would require assessing how unobservable factors attract immigrants. The following section examines the potential threat to the internal validity of these results due to reverse causality.

\footnotetext{
10 Since the logarithm of GDP is used in the regression, the estimate for non-EU immigration flows means that a $1 \%$ change on GDP is associated with a change of immigration flows from $0.44 \%$, the mean value, to around $0.45 \%$.

${ }^{11}$ Since the inclusion of fixed effects absorbs cross-country, time-unvarying differences, a potential explanation for this weak relationship is that unemployment within each country does not vary substantially over time. Inspection of the unemployment rates confirms this conjecture: only Ireland, the Slovak Republic and Spain exhibit important changes during the period under analysis, while unemployment rates are rather constant for the remaining countries.

${ }^{12}$ The estimates of the other components for non-EU immigration flows are 0.066 (s.e. 0.035 ) for family expenditure, -0.028 (s.e. 0.014) for health expenditure and -0.039 (s.e. 0.025) for pension expenditure. For EU flows, the corresponding estimates are -0.001 (s.e. 0.010 ), 0.004 (s.e. 0.006 ) and -0.011 (s.e. $0.008)$.
} 
Table 1: OLS estimates of immigration inflow rates

\begin{tabular}{|c|c|c|c|c|}
\hline & (a) & (b) & $(\mathrm{c})$ & $(\mathrm{d})$ \\
\hline & \multicolumn{4}{|c|}{ Non-EU immigrants } \\
\hline \multirow{2}{*}{ UBS } & & $0.058 * *$ & $0.061^{*}$ & $0.066^{* * *}$ \\
\hline & & $(0.028)$ & $(0.031)$ & $(0.021)$ \\
\hline \multirow[t]{2}{*}{ Stock of non-EU immigrants } & $0.141^{* * *}$ & $0.129 * * *$ & $0.123^{* * *}$ & $0.079^{*}$ \\
\hline & $(0.028)$ & $(0.026)$ & $(0.028)$ & $(0.039)$ \\
\hline \multirow[t]{2}{*}{ Per-capita GDP } & $0.017^{* *}$ & $0.019^{* *}$ & $0.018^{* *}$ & 0.007 \\
\hline & $(0.007)$ & $(0.007)$ & $(0.007)$ & $(0.004)$ \\
\hline \multirow[t]{2}{*}{ Unemployment rate } & -0.007 & -0.015 & -0.005 & -0.026 \\
\hline & $(0.018)$ & $(0.017)$ & $(0.016)$ & $(0.015)$ \\
\hline \multirow[t]{2}{*}{ Constant } & $-0.056^{* *}$ & $-0.063^{* *}$ & $-0.053^{* *}$ & -0.020 \\
\hline & $(0.023)$ & $(0.024)$ & $(0.021)$ & $(0.014)$ \\
\hline \multirow[t]{2}{*}{$\bar{R}^{2}$} & 0.64 & 0.65 & 0.68 & 0.52 \\
\hline & \multicolumn{4}{|c|}{ EU immigrants } \\
\hline \multirow{2}{*}{ UBS } & & -0.009 & -0.003 & -0.012 \\
\hline & & $(0.012)$ & $(0.013)$ & $(0.013)$ \\
\hline \multirow[t]{2}{*}{ Stock of EU immigrants } & $0.072^{* * *}$ & $0.075^{* * *}$ & $0.068^{* *}$ & $0.094^{* * *}$ \\
\hline & $(0.021)$ & $(0.025)$ & $(0.027)$ & $(0.021)$ \\
\hline \multirow[t]{2}{*}{ Per-capita GDP } & 0.000 & 0.000 & 0.000 & -0.003 \\
\hline & $(0.002)$ & $(0.003)$ & $(0.003)$ & $(0.003)$ \\
\hline \multirow[t]{2}{*}{ Unemployment rate } & 0.001 & 0.002 & 0.004 & 0.006 \\
\hline & $(0.005)$ & $(0.006)$ & $(0.006)$ & $(0.005)$ \\
\hline \multirow{2}{*}{ Constant } & 0.000 & 0.001 & 0.002 & 0.008 \\
\hline & $(0.006)$ & $(0.007)$ & $(0.007)$ & $(0.010)$ \\
\hline $\bar{R}^{2}$ & 0.28 & 0.29 & 0.29 & 0.37 \\
\hline Weights & $\mathrm{Y}$ & $\mathrm{Y}$ & $\mathrm{Y}$ & $\mathrm{N}$ \\
\hline Other welfare components & $\mathrm{N}$ & $\mathrm{N}$ & $\mathrm{Y}$ & $\mathrm{N}$ \\
\hline $\mathrm{N}$ & 248 & 248 & 248 & 248 \\
\hline
\end{tabular}

\subsection{Is unemployment benefit spending endogenous?}

Two potential channels of endogeneity that might threaten the causal interpretation of the OLS estimates are now discussed. Both are cases of reverse causality, whereby social expenditure is a function of immigration. Presence of simultaneity bias is best explained by the means of the following system of equations:

$$
\left\{\begin{array}{c}
m=\beta s+\varepsilon \\
s=\gamma m+\eta
\end{array}\right.
$$

Equation (2a) is a simplified version of (1), and equation (2b) states that social welfare spending is a function of immigration. Estimation of (2a) by OLS will lead to simultaneity bias, since:

$$
p \lim \beta=\beta_{O L S}+\operatorname{Cov}\left(\frac{\gamma \varepsilon+\eta}{1-\beta_{O L S} \gamma}, \varepsilon\right) \times \frac{1}{\operatorname{Var}(m)}=\beta_{O L S}+\frac{\gamma \sigma_{\varepsilon}^{2}+\eta}{1-\beta_{O L S} \gamma} \times \frac{1}{\operatorname{Var}(m)}
$$


Equation (3) shows that the size and magnitude of the bias depend (among other things) on the size and magnitude of $\gamma$, which capture the impact of immigration on spending. For example, the OLS analysis might conclude that there is a positive (negative) welfare magnet effect. However, the true, exogenous impact of UBS on immigration could be much smaller (larger) in presence of positive (negative) bias. The following two channels of simultaneity bias are explored: a) the co-determination of immigration and UBS and b) the responsiveness of welfare policies to immigration.

The first possible channel is a consequence of the simultaneous determination of immigration and UBS. This occurs because immigrants access welfare and hence they affect $s$, the level of spending in equation (2b). Moreover, since UBS is expressed as a percentage of GDP, immigration simultaneously affects both the numerator (the amount of spending) and the denominator (how immigrants participate to the GDP through consumption, taxes and welfare spending). While it is difficult to provide a precise assessment of the effect of immigration on welfare spending, an indirect account can be given by comparing the welfare use of immigrants to natives. This is done in Table 2, where data for unemployment benefit recipiency are reported for natives, EU immigrants and non-EU immigrants for the years 2005-2008. In particular, the first three columns report the unconditional take-up rates (percentage of individuals in each group who receive unemployment benefits). With few exceptions, non-EU and EU immigrants show substantially higher unconditional probabilities of taking-up unemployment benefits than natives, determining a "disproportional" spending attributable to immigrants. However, these raw statistics do not take into account the diverse composition of immigrant groups. To this aim, the remaining columns of Table 2 report the probability of receiving unemployment benefits conditional on unemployment status and on socio-demographic characteristics (see Brücker et al., 2002). ${ }^{13}$ After controlling for these characteristics, there is no longer evidence that immigrants take-up benefits more than natives; if anything, immigrants (particularly those from non-EU origins) exhibit lower rates of unemployment benefit recipiency. This evidence is in line with Barrett and Maître (forthcoming), who find that after conditioning for unemployment status, immigrants are less likely than natives to receive unemployment benefits. On the one hand, the disproportional benefit spending attributable to immigrants suggests that it is indeed important to take into account reverse causality, as immigration might then lead to increased welfare spending. However, the figures in Table 2 also suggest that the relatively higher spending attributable to immigrants is the result of the composition of immigrant population rather than a consequence of their residual propensity to take-up welfare (holding characteristics constant).

The second possible cause of simultaneity bias explored is related to the responsiveness of unemployment benefit policies to immigration, given that institutions in the host country could intervene on expenditure legislation in response to high immigration. For example, if there is the perception of excessive expenditure caused by immigrant welfare dependency (i.e., immigrants take-up benefits more than they supply to the system through social contributions),

\footnotetext{
${ }^{13} \mathrm{~A}$ probit model is estimated for each of the three groups, pooling EU-SILC data for the years 20052008. The dependent variable is the probability of accessing unemployment benefits conditional on being unemployed. The explanatory variables contain gender, age, education and dummies for the country of residence. Observations are weighted by population size. Full estimates are available upon request.
} 
Table 2: Unemployment benefit recipiency, 2005-2008

\begin{tabular}{lcccccc}
\hline \hline & \multicolumn{3}{c}{ Unconditional take-up rates } & \multicolumn{3}{c}{ Conditional take-up rates } \\
Country & Natives & Non-EU & EU & Natives & Non-EU & EU \\
\hline Austria & 0.091 & 0.195 & 0.106 & 0.631 & 0.661 & 0.567 \\
Belgium & 0.148 & 0.193 & 0.162 & 0.813 & 0.766 & 0.772 \\
Czech Republic & 0.049 & 0.035 & 0.049 & 0.331 & 0.242 & 0.232 \\
Denmark & 0.201 & 0.335 & 0.242 & 0.639 & 0.747 & 0.757 \\
Finland & 0.188 & 0.464 & 0.233 & 0.846 & 0.853 & 0.871 \\
France & 0.097 & 0.148 & 0.091 & 0.546 & 0.495 & 0.519 \\
Germany & 0.113 & $0.153^{\dagger}$ & 0.721 & $0.715^{\dagger}$ \\
Hungary & 0.071 & 0.028 & 0.040 & 0.543 & 0.324 & 0.600 \\
Ireland & 0.108 & 0.093 & 0.092 & 0.622 & 0.495 & 0.543 \\
Italy & 0.121 & 0.204 & 0.184 & 0.239 & 0.285 & 0.314 \\
Luxembourg & 0.021 & 0.059 & 0.049 & 0.269 & 0.307 & 0.406 \\
Netherlands & 0.051 & 0.065 & 0.060 & 0.448 & 0.236 & 0.511 \\
Norway & 0.044 & 0.102 & 0.054 & 0.351 & 0.378 & 0.316 \\
Portugal & 0.046 & 0.050 & 0.056 & 0.325 & 0.295 & 0.301 \\
Slovak Republic & 0.030 & $0.013^{\dagger}$ & 0.175 & $0.109^{\dagger}$ \\
Spain & 0.066 & 0.061 & 0.066 & 0.326 & 0.230 & 0.253 \\
Sweden & 0.102 & 0.160 & 0.098 & 0.380 & 0.315 & 0.393 \\
United Kingdom & 0.017 & 0.025 & 0.017 & 0.368 & 0.331 & 0.324 \\
\hline Average & 0.086 & 0.124 & 0.103 & 0.487 & 0.458 & 0.447 \\
\hline \hline
\end{tabular}

Source: EU-SILC 2005 to 2008. Notes: ${ }^{\dagger}$ Breakdown by EU/non-EU immigrants not available, figures refer to the average rate for the two groups. Data for Switzerland are not available.

then governments are more prone to reform aspects of the public insurance system that might discourage immigration (or favour return migration), such as eligibility criteria (contributions) and durations. Changes in these characteristics will, in turn, influence the level of UBS. ${ }^{14}$ If this is the case, one would expect high-immigration countries to implement austere changes in the unemployment benefit system. To explore this hypothesis, Table 3 reports the levels of and the changes in the eligibility criteria (expressed by the months of employment contributions necessary to qualify for unemployment benefit) and in the duration of unemployment benefits, for the period 1999-2007 (for which these data are available). Countries have been ranked in terms of non-EU immigration impact, represented by the change in the stock of immigrants as percentage of the population. There is no evidence that high immigration countries adopted more restrictive measures in terms of eligibility criteria. On the contrary, unemployment benefit duration has been reduced more in countries with relatively lower changes in immigration. This suggests the existence of a positive, although weak, impact of immigration on UBS, and further justifies the efforts to explore the reverse causality in welfare magnet hypothesis.

\footnotetext{
${ }^{14}$ For example, Razin et al. (2002) argue that migration (in particular low-skilled migration) may lead to a lower tax burden in the long-run. They reason that there will be income redistribution as a consequence of immigration, with native-born individuals moving towards the higher (and anti-tax) part of the income distribution.
} 
Table 3: Employment contributions and durations of unemployment benefits

\begin{tabular}{|c|c|c|c|c|c|c|}
\hline \multirow[t]{2}{*}{ Country } & \multirow{2}{*}{$\begin{array}{c}\text { Stock non-EU } \\
\Delta\end{array}$} & \multirow{2}{*}{$\begin{array}{c}\text { Stock EU } \\
\Delta\end{array}$} & \multicolumn{2}{|c|}{ Contributions } & \multicolumn{2}{|c|}{ Durations } \\
\hline & & & In 1999 & $\Delta$ & In 1999 & $\Delta$ \\
\hline Spain & 7.85 & 1.58 & 12 & 0 & 24 & 0 \\
\hline Luxembourg & 4.72 & 1.15 & 7 & 0 & 12 & 0 \\
\hline Italy & 3.45 & -0.02 & 12 & 0 & 6 & 1 \\
\hline United Kingdom & 2.40 & 0.10 & 24 & -12 & 6 & 0 \\
\hline Ireland & 1.61 & 0.06 & 10 & 0 & 15 & 0 \\
\hline Portugal & 1.59 & 0.32 & 18 & -9 & 30 & -6 \\
\hline Czech Republic & 1.41 & 0.16 & 12 & 0 & 6 & 0 \\
\hline Norway & 1.30 & 0.34 & 12 & 0 & 36 & -12 \\
\hline Finland & 0.72 & 0.10 & 11 & 0 & 25 & -2 \\
\hline Austria & 0.62 & 0.74 & 12 & 0 & 10 & -1 \\
\hline Switzerland & 0.52 & 1.12 & 6 & 6 & 7 & 11 \\
\hline Denmark & 0.34 & 0.25 & 12 & 0 & 60 & -12 \\
\hline Sweden & 0.26 & -0.03 & 6 & 0 & 15 & -1 \\
\hline Slovak Republic & 0.21 & 0.21 & 24 & 12 & 9 & -3 \\
\hline Hungary & 0.16 & 0.08 & 12 & 0 & 12 & -3 \\
\hline France & 0.07 & 0.12 & 4 & 2 & 60 & -37 \\
\hline Netherlands & 0.01 & 0.07 & 7 & 0 & 60 & -22 \\
\hline Belgium & -0.01 & 0.38 & 21 & 6 & 60 & 0 \\
\hline Germany & -1.24 & 0.50 & 12 & 0 & 12 & 0 \\
\hline
\end{tabular}

\subsection{IV estimates}

The potential endogeneity issues just discussed can be addressed by means of an IV approach. In other words, in order to provide a causal interpretation to the welfare magnet hypothesis, a variable which is correlated with the exogenous part of expenditure but not with immigration shocks is required. The number of parties in the government coalition is chosen as the IV for UBS. This choice is motivated by an empirical study by Bawn and Rosenbluth (2006), which shows that public sectors are larger when coalitions are formed by more political parties. The rationale is that in larger coalitions each party is liable only for a fraction of the government political choices, resulting in greater public spending. ${ }^{15}$

The relevance of the instrument is explored by examining the first stage of the regression. This is done in Figure 1, where values of UBS (conditioning for all covariates in equation (1) are plotted against the number of parties in the government coalition. The figure shows a strong correlation between the two variables - in particular, the estimate of the number of parties is 0.0019 (s.e.

\footnotetext{
${ }^{15} \mathrm{~A}$ similar argument is used by Milesi-Ferretti et al. (2002), who document that proportional systems favour social welfare spending, while majoritarian systems are more likely to redistribute resources through public goods.
} 
0.0006). ${ }^{16}$ Instrument exogeneity requires that the number of parties is not correlated with the error term in the immigration equation. Although it is possible that election results are affected by immigration rates or that new parties arise as a consequence of high immigration, this is unlikely to alter the composition of the winning coalition in terms of number of parties it is composed of. In order to provide further evidence to the results above, a dynamic model is considered, whereby the lagged immigration inflows is included as explanatory variable. The Arellano-Bond's system GMM technique is employed as the estimating strategy. ${ }^{17}$

Figure 1: Predicted UBS (y-axis) and number of parties in governing coalition (x-axis).

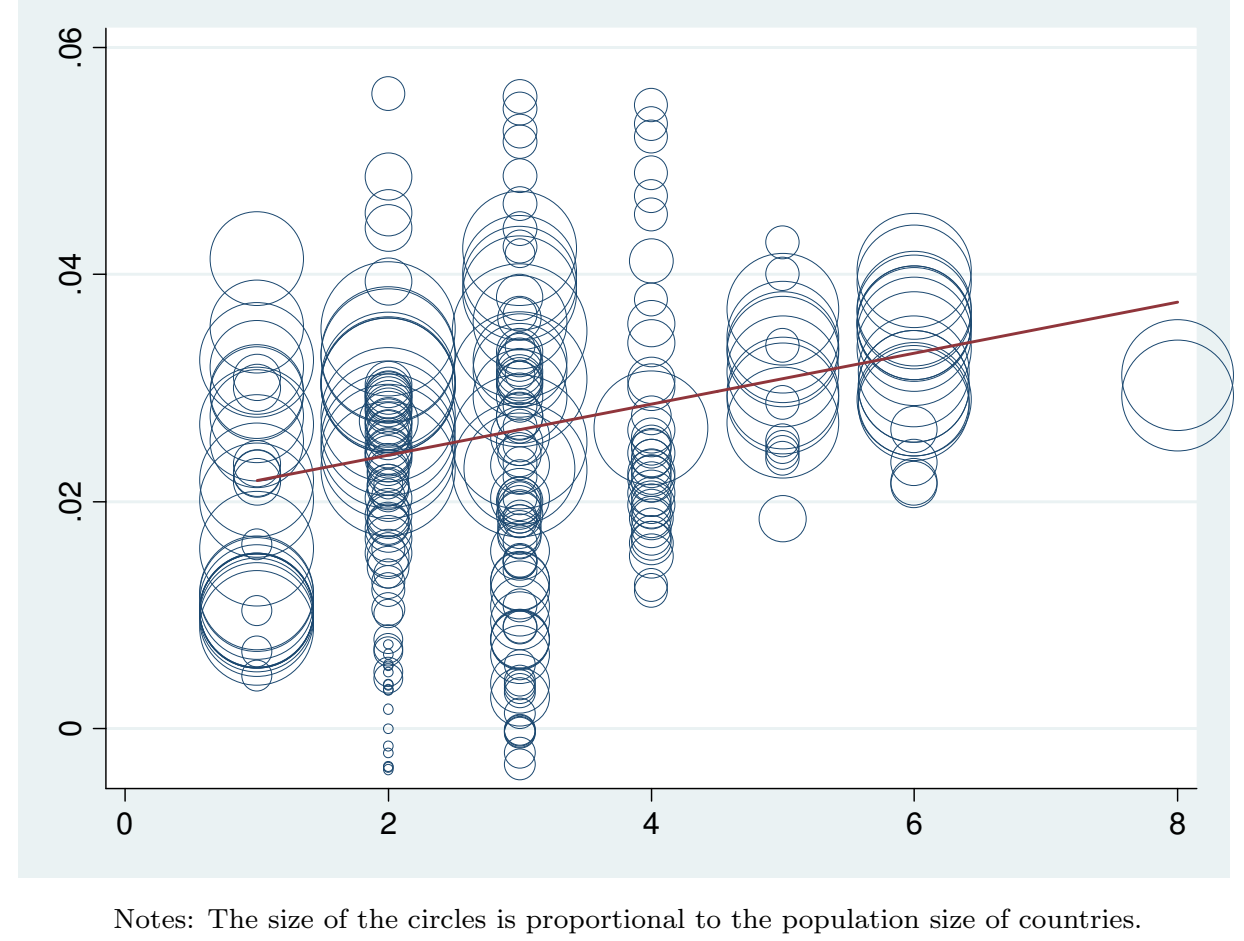

Table 4 presents the results related to IV and GMM estimations. After taking endogeneity into account, the coefficient for non-EU immigrants is essentially zero and statistically insignificant. On the one hand, these estimates suggest that, in the context of unemployment benefits, the welfare magnet hypothesis seems not at work; on the other hand, they reveal the presence of an upward bias in the OLS. For EU immigrants, IV and GMM estimates confirm the absence of any effect, as found in Table $1 .^{18}$

\footnotetext{
${ }^{16}$ Shea's $R^{2}$ is 0.11 and the Cragg-Donald Wald F-statistic is 26.78 . In only three countries (Austria, Luxembourg and the United Kingdom) did the number of parties in the governing coalition exhibit no variation over time.

${ }^{17}$ System GMM is an augmented version of GMM that uses system of two equations, one differenced and one in levels. Variables in levels are instrumented with their first differences to increase efficiency. The second lag of the endogenous variables is used as instrument because it is not correlated with the error term.

${ }^{18}$ In the GMM estimates, essentially all regressors are insignificant, since most of their explanatory power is absorbed by the lagged dependent variable.
} 
Table 4: IV and Arellano-Bond estimates of immigration inflow rates

\begin{tabular}{|c|c|c|c|c|}
\hline & \multicolumn{2}{|c|}{ Non-EU immigrants } & \multicolumn{2}{|c|}{ EU immigrants } \\
\hline & IV & GMM & IV & GMM \\
\hline \multirow[t]{2}{*}{ UBS } & 0.040 & -0.013 & -0.004 & 0.001 \\
\hline & $(0.065)$ & $(0.034)$ & $(0.022)$ & $(0.007)$ \\
\hline \multirow[t]{2}{*}{ Immigrants inflow (t-1) } & & $0.785^{* * *}$ & & $1.037^{* * *}$ \\
\hline & & $(0.123)$ & & $(0.152)$ \\
\hline \multirow[t]{2}{*}{ Stock of immigrants } & $0.133^{* * *}$ & 0.002 & $0.073^{* * *}$ & -0.015 \\
\hline & $(0.018)$ & $(0.021)$ & $(0.014)$ & $(0.016)$ \\
\hline \multirow[t]{2}{*}{ Per-capita GDP } & $0.019 * * *$ & 0.004 & 0.000 & 0.000 \\
\hline & $(0.003)$ & $(0.003)$ & $(0.001)$ & $(0.001)$ \\
\hline \multirow[t]{2}{*}{ Unemployment rate } & -0.012 & -0.001 & 0.002 & 0.001 \\
\hline & $(0.011)$ & $(0.007)$ & $(0.003)$ & $(0.001)$ \\
\hline \multirow[t]{2}{*}{ Constant } & $-0.068 * * *$ & -0.013 & 0.002 & 0.000 \\
\hline & $(0.012)$ & $(0.011)$ & $(0.005)$ & $(0.002)$ \\
\hline $\mathrm{N}$ & 248 & 248 & 248 & 248 \\
\hline \multicolumn{5}{|c|}{ Notes: Robust standard errors in parentheses. ${ }^{*} / * * / * *$ indicate significance at the $10 / 5 / 1 \%$ level. } \\
\hline \multicolumn{5}{|c|}{$\begin{array}{l}\text { All models are estimated using country fixed effects and contain year dummies. All regressions are } \\
\text { weighted by the counts of individuals in each country in the year } 2000 \text {. Instrument is the number } \\
\text { of parties in the winning parliamentary coalition. IV estimates are computed using Stata command } \\
\text { xtivreg2 developed by M.E. Schaffer (Schaffer, 2005). GMM estimates are obtained using Stata } \\
\text { command xtabond } 2 \text { by D. Roodman (Roodman, 2009). }\end{array}$} \\
\hline
\end{tabular}

The presence of endogeneity indicates the existence of effects from immigration on UBS. It remains a topic for further research whether this is because immigrants access unemployment benefits with different intensity than natives, or because their contribution to GDP is relatively different to their program participation, or, finally, because policy makers' welfare generosity responds to immigration. Evidence was provided that these channels may be operative.

\section{Conclusions}

This paper has explored the role of UBS on immigration using a sample of EU countries during the period 1993-2008. While the OLS analysis revealed the presence of a moderate correlation between social welfare spending and immigration from non-EU origins, the IV and GMM estimates indicate that the causal effect is smaller and statistically insignificant, thereby rejecting the welfare magnet hypothesis. All estimates for EU immigrants are essentially zero, which suggests that immigration within the EU does not respond to unemployment benefit incentives. Although the results are robust across specifications, it is important to point out potential limitations of the analysis. On the one hand, the absence of information detailing the country of origin, especially for immigration from outside the EU, might be confounding the existence of welfare magnet effects. Although the effect of UBS on immigration is zero on average, it is not possible to exclude that for immigrants from certain origins, unemployment benefits constitute a strong incentive to immigrate. Future availability of detailed data will allow the exploration 
of this hypothesis. As for EU immigrants, the finding that the estimated effect is essentially zero could be determined by either the fact that they are more skilled, and hence less likely to be attracted by welfare states (Brücker, 2002), or simply by their freedom of movement within the EU, which leads them to rely on (or refer to) their home country unemployment benefit system.

Finally, some descriptive evidence that the positive correlation between welfare and immigration arises due to two channels was provided. First, inappropriate immigration policies in Europe may lead to an adverse composition of immigrants, which in turn results in a higher unemployment benefit take-up rate on the part of immigrants. Second, welfare policies may become more generous in wake of immigration. These are fruitful areas for future research. 


\section{References}

Anastassova, L. and T. Paligorova (2005). Why Immigrants Manage to Grab More Social Benefits? Empirical Cross-Country Analysis. CERGE-EI Working Papers.

Barrett, A. and B. Maître (forthcoming). Immigrant welfare receipt across Europe. International Journal of Manpower.

Bawn, K. and F. Rosenbluth (2006). Short versus Long Coalitions: Electoral Accountability and the Size of the Public Sector. American Journal of Political Science 50(2), 251-265.

Boeri, T. and H. Brücker (2005). Migration, Co-ordination Failures and EU Enlargement. IZA Discussion Papers.

Borjas, G. J. (1999). Immigration and Welfare Magnets. Journal of Labor Economics, 607-637.

Brücker, H. (2002). Can International Migration Solve the Problems of European Labour Markets? Economic Survey of Europe, 109-135.

Brücker, H., G. S. Epstein, B. McCormick, G. Saint-Paul, A. Venturini, and K. F. Zimmermann (2002). Welfare State Provision. Immigration Policy and the Welfare System. Oxford University Press, London, 66-90.

Cohen, A., A. Razin, and E. Sadka (2009). The Skill Composition of Migration and the Generosity of the Welfare State.

De Giorgi, G. and M. Pellizzari (2009). Welfare Migration in Europe. Labour Economics 16(4), 353-363.

Heitmueller, A. (2005). Unemployment Benefits, Risk Aversion, and Migration Incentives. Journal of Population Economics 18(1), 93-112.

Milesi-Ferretti, G. M., R. Perotti, and M. Rostagno (2002). Electoral Systems and Public Spending. Quarterly Journal of Economics 117(2), 609-657.

Nannestad, P. (2007). Immigration and Welfare States: A survey of 15 Years of Research. European Journal of Political Economy 23(2), 512-532.

OECD (2002). Benefits and Wages 2002: OECD indicators.

OECD (2007). Benefits and Wages 2007: OECD indicators.

Pedersen, P. J., M. Pytlikova, and N. Smith (2008). Selection and Network Effects-Migration Flows into OECD Countries 1990-2000. European Economic Review 52(7), 1160-1186.

Razin, A., E. Sadka, and P. Swagel (2002). Tax Burden and Migration: A political Economy Theory and Evidence. Journal of Public Economics 85(2), 167-190. 
Roodman, D. M. (2009). How to do xtabond2: An Introduction to Difference and System GMM in Stata. Stata Journal 9(1), 86-136.

Schaffer, M. E. (2005). xtivreg2: Stata Module to Perform Extended IV/2SLS, GMM and AC/HAC, LIML and k-class regression for panel data models. Statistical Software Components. 


\section{Appendix}

a) Description of SOPEMI database

Information on stocks and inflows of foreign population in European countries is taken from the SOPEMI database. Data on foreign population and nationals is generally collected either from population registers or residence permit database, and covers the following periods: Austria 1996-2008, Belgium 1993-2007, Czech Republic 1995-2008, Denmark 1993-2007, Finland 19932008, France 1994-2008, Germany 1993-2008, Hungary 1995-2008, Ireland 1994-2004, Italy 19932007, Luxembourg 1993-2006, Netherlands 1993-2008, Norway 1993-2008, Portugal 1993-2007, Slovak Republic 1993-2008, Spain 1998-2007, Sweden 1993-2003, Switzerland 1993-2008, United Kingdom 1997-2008. 


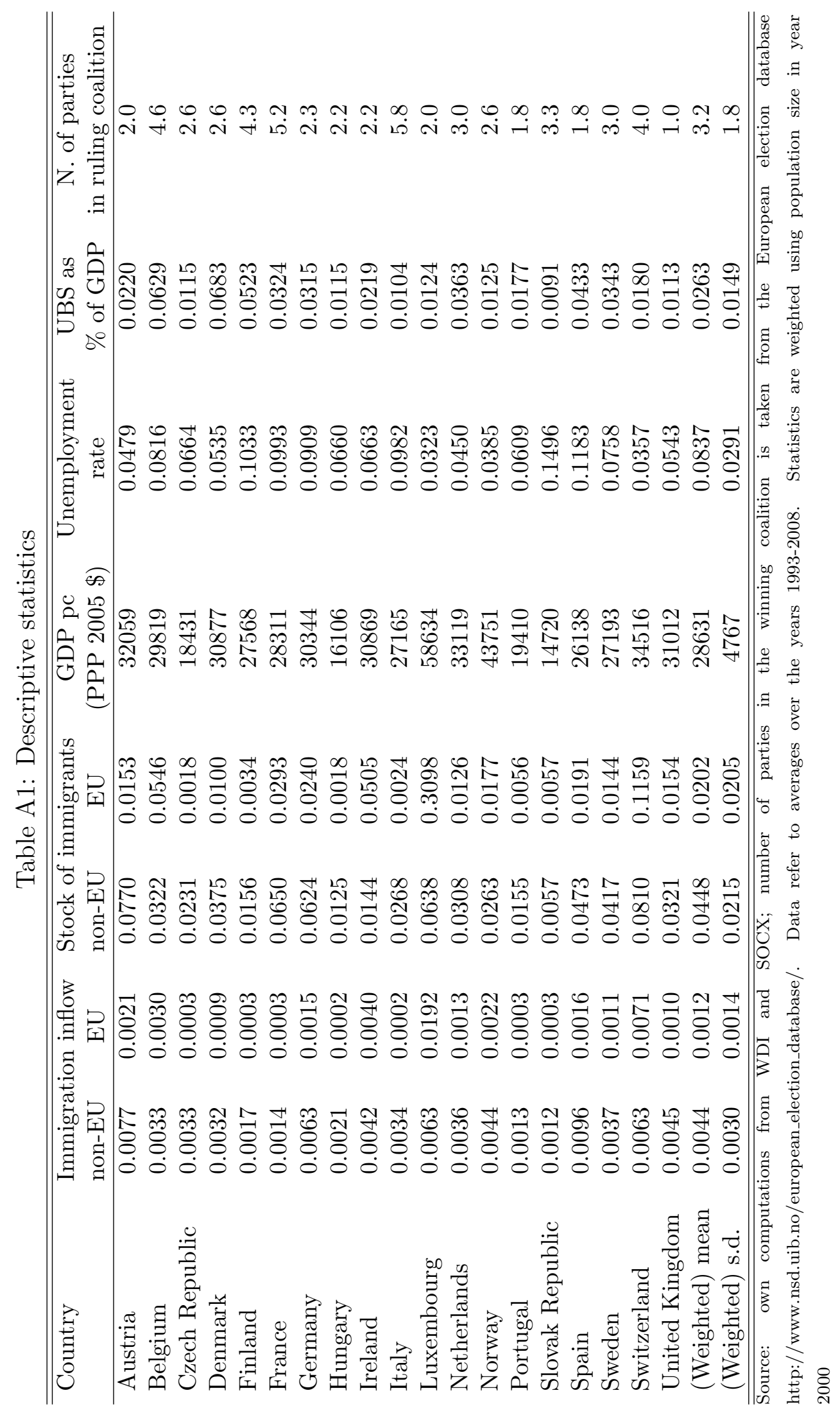

